\title{
VJEROUČITELJI I VJEROUČITELJICE NA NEKIM IZVORIMA SAKRAMENTALNE DUHOVNOSTI
}

\author{
Kata s. Amabilis Jurić
}

Katolički bogoslovni fakultet

UDK: (303.442+005.571):27-55

Sveučilišta u Zagrebu

kata.juric@kbf.unizg.hr

\author{
https://doi.org/10.34075/cs.56.4.2 \\ Izvorni znanstveni rad \\ Rad zaprimljen 3/2021.
}

\section{Sažetak}

Iz Katekizma Katoličke Crkve i teološke literature proizlazi da su sakramenti 'žarišne točke' Božjeg djelovanja u Crkvi i ostvarenje njezinog spasenjskog poslanja evidentnog u životu i djelovanju suvremenog vjeroučitelja. U prvom dijelu znanstvenog rada predstavljen je službeni nauk Crkve te teološka promišljanja relevantnih autora o sakramentima, posebice pomirenja, euharistije i ženidbe, kojima su vjeroučitelji pridavali većinsku pozornost u kvalitativnom istraživanju. Njihova interpretacija oslanja se na neke uporišne točke suvremene kršćanske sakramentologije, što je predmet drugog dijela znanstvenog diskursa, koji u središte promišljanja stavlja konkretna poimanja $i$ očitovanja vjeroučiteljeve sakramentalne duhovnosti dobivene kvalitativnim istraživanjem, metodom napola strukturiranog ili dubinskog intervjua, u čemu se ujedno očituje i novost ovoga rada. Intervjuirani vjeroučitelji potvrđuju važnost teorijskih promišljanja o sakramentima, no ipak prednost daju konkretnom sujedočkom življenju usvojenih sadržaja i njihovu prenošenju na vjeroučenike.

Ključne riječi: sakramenti, sakrament pomirenja, sakrament euharistije, sakrament ženidbe, kvalitativno istraživanje, dubinski intervju.

\section{UVOD}

Kršćanski govor o sakramentima nedvojbeno je vezan uz sadržajnu tematiku Katekizma Katoličke Crkve te kršćanske teologije o sakramentima, koja se u ovom radu podrazumijeva. U našem ćemo se diskursu u uvodnom dijelu rada tematski usredotočiti na antropološko-teološka promišljanja pod vidom susreta čovjeka i Boga, koji se upravo događa u sakramentima kao izvorima sakramentalne duhovnosti koji su od presudne važnosti za kršćanski život i djelovanje vjeroučitelja/ica vjernikâ laikâ za ovo naše vrijeme. 
Prema Katekizmu Katoličke Crkve „sakramenti su djelotvorni znakovi milosti, ustanovljeni od Isusa Krista i povjereni Crkvi, kojima nam se podjeljuje božanski život". ${ }^{1}$ Kada se govori o sakramentima, onda se misli upravo na znakovite čine Crkve po kojima se događa i ostvaruje susret s Bogom. Simbolično kazano „može se reći da su sakramenti ondje gdje se ljube nebo i zemlja. Gdje Bog i čovještvo postaju jedno: Bog je nevidljiv; sakramenti nam dopuštaju da ga vidimo pod velom vidljivih stvari. Bog je nedodirljiv; sakramenti nam dopuštaju da ga dodirnemo; Bog je nepriopćiv; preko sakramenata ulazimo u zajedništvo s Njime". ${ }^{2}$ S druge strane, novozavjetne sakramente Crkve također možemo promatrati u slici gorućeg grma, kao od Krista zapaljenog bogoštovnog ognja, kao sakramentalni plamen Božje milosti, kao sakramentalno otajstvo susreta i dijaloga, dodira i komunikacije između Boga i čovjeka. Valja primijetiti da su subjekti teologije sakramenata Bog i čovjek, jer Bog djeluje spasenjski, a čovjek je potreban Božjeg spasonosnog djelovanja. U novije se vrijeme u kršćanskoj sakramentologiji naglašava interaktivni odnos koji uključuje odnos Boga prema čovjeku i taj vid predstavlja silazni put, dok odnos čovjeka prema Bogu predstavlja uzlazni put. Upravo tu leži teološko i antropološko obzorje teologije sakramenata zbog kojih ih dogmatska disciplina ne može zaobići. ${ }^{3}$ Jedan drugi relevantni autor za promišljanje o našoj temi vidi antropološko utemeljenje sakramenata već u ljudskoj naravi i načinima kojima se čovjek ostvaruje kao osoba. Prema njemu, sakramenti su priopćavanja, odnosno susreti ili put do sreće, zato što se ključ kršćanske vjere i teologije nalazi u osobnom susretu s Kristom koji susret sakramenti antropološki i otajstveno ostvaruju. ${ }^{4}$ Nadalje, tajna sakramenata događa se u vjeri i zajednici koji konačno vode k spasenju. Stoga se s pravom može ustvrditi da su sakramenti mjesto susreta, dijaloga i životnog dodira s Kristom u Crkvi. ${ }^{5}$ Na tom tragu, za sve vjernike, kao i za vjeroučitelje „sakramenti su egzistencijalni živi događaji koji oživljuju duhovno zamrle, koji okrepljuju duhovno klonule, koji ozdravljaju dušu i tijelo, koji vraćaju u stanje milosti, koji oprav-

1 Hrvatska biskupska konferencija, Katekizam katoličke Crkve, Glas Koncila, Zagreb, 2016., br. 1131., (dalje: KKC).

2 Ivan Karlić, Sveti sakramenti. Susret s Isusom Kristom u sakramentima Crkve, Kršćanska sadašnjost, Zagreb, 2014., 12.

3 Usp. Niko Ikić, Teologija sakramenata. 'Gorući grm' sakramentalne milosti, Katolički bogoslovni fakultet Sarajevo i Glas Koncila, Zagreb, 2012., 11 i 19.

$4 \quad$ Usp. Ante Mateljan, Otajstvo susreta. Temeljna sakramentologija, Crkva u svijetu, Split, 2010., 7-8 i 17-18.

$5 \quad$ Usp. Dušan Moro, Krist - Crkva - sakramenti. Komunitarni smisao i određenost sakramenata, Služba Božja, 31 (1991.) 1, 3-17, ovdje 17. 
davaju sve ljudske grijehe, pa i onaj iskonski, koji osposobljavaju slabe za crkvene službe, koji životno združuju u ljubavi, koji realno sjedinjuju u Tijelu i Krvi Kristovoj sa samim Isusom, koji milost ne samo naznačuju nego djeluju i posvećuju". ${ }^{6}$ Zato su Božja remekdjela po Crkvi i za Crkvu (KKC, br. 1116. i 1118.).

U odnosu na kvalitativna istraživanja valja spomenuti da su ih urednici sveobuhvatnog američkog priručnika kvalitativne metodologije Denzin i Lincoln ${ }^{7}$ odredili kao ponajprije metodski pristup koji se temelji na tumačenju subjektivnih pojava, što je i evidentno $\mathrm{u}$ vjeroučiteljskim iskazima. U tom kontekstu kvalitativni pristup proučava fenomene u njihovu prirodnom okruženju, nastoji im dati smisao i tumačenje sukladno značenju koje im pridaju ljudi. Stoga se kvalitativne metode temelje na analizi tekstualne građe nastale na temelju osobnih iskustava, životnih priča, pojedinačnih ili skupnih intervjua, opažanja i svih drugih dokumenata koji podjednako opisuju svakodnevna i trenutačna događanja značajna za život pojedinca. Prema mišljenju G. Milasa ${ }^{8}$ kvalitativne metode povećavaju naše razumijevanje problema, jer je razina analize daleko detaljnija i dublja nego što je to slučaj u tradicionalnim istraživačkim metodama, što je bio i razlog opredjeljenja autorice za ovaj način istraživanja. Nadalje, čini se uputnim naglasiti da je u raspravama o odnosu između filozofsko-teološkog područja i empirijskih društvenih istraživanja na njemačkome jezičnom području ${ }^{9}$ postalo evidentno da se je u empirijskim sociološkim istraživanjima za područje teološkog ispitivanja kao jedna od najprikladnijih udomaćila metoda narativnog intervjua. ${ }^{10}$ Također se preporuča kombinacija slobodnog pri-

6 Usp. Niko Ikić, Prikaz knjige Ante Mateljana, Otajstvo susreta. Temeljna sakramentologija, Crkva u svijetu, Split, 2010., str. 227., recenzije, Bogoslouska smotra, 81 (2011.) 4, 1027-1029, ovdje 1029.

7 Usp. Norman Denzin - Yvonna Lincoln (ur.), Handbook of qualitative research, Thousand Oaks: Sage, London, 1994., citirano prema: Goran Milas, Istraživačke metode $u$ psihologiji $i$ drugim društvenim znanostima, Naklada Slap, Zagreb, 2005., 583.

$8 \quad$ Usp. Isto, 571-572.

9 Usp. Norbert Mette - Hermann Steinkamp, Sozialwissenschaften und Praktische Theologie, Patmos Verlag, Düsseldorf, 1983.; Gottfried Bitter - Gabrielle Miller, Neues Handbuch religionspädagogischer Grundbegriffe, Karl Ernst Nipkow, München, 2002. O važnosti pripovijedanja vidi također u: Paul M. Zulehner, Das Gottesgerücht. Bausteine für eine Kirche der Zukunft, Patmos Verlag, Düsseldorf, 1989.

10 O teorijskim razlozima usklađenosti društveno-znanstvenih i teoloških pristupa vidi u: Stefanie Klein, Theologie und Biographieforschung. Methodische Zugänge zu dem Lebens- und Glaubensgeschichte und ihre Bedeutung für eine erfahrungsbezogene Theologie, Book on Demand, Stuttgart - Berlin - Köln, 1994. 
povijedanja i unaprijed pripremljenih pitanja. Riječ je o tzv. napola strukturiranom ili dubinskom intervju (halbstrukturiertes-leitfadenorientiertes) orijentiranom na misao vodilju, u kojem su unaprijed formulirana otvorena pitanja prilagođena tijeku razgovora. ${ }^{11}$ Što se tiče uzorka kvalitativnih istraživanja važno je napomenuti da za razliku od anketnih kvantitativnih istraživanja, čiji se rezultati temelje na odgovorima na pitanja ispitanika čiji je uzorak brojčano puno veći (stotine pa i tisuće), dubinski se intervjui u pravilu realiziraju na namjerno odabranom uzorku čije se mišljenje želi upoznati. ${ }^{12}$

$\mathrm{U}$ istraživanju provedenom s vjeroučiteljima/icama u osnovnim i srednjim školama u Republici Hrvatskoj uvažena su načela kvalitativnog istraživanja te metoda već spomenutog napola strukturiranog intervjua, koji pruža mogućnost da svaki razgovor posjeduje svoju nit vodilju. Istraživanje je provedeno na uzorku od 41 vjeroučitelja/ ica razmjerno raspoređenih prema cjelokupnom broju vjeroučitelja/ ica u nadbiskupijama i biskupijama u Republici Hrvatskoj u vremenskom razdoblju od konca kolovoza do početka prosinca 2010. godine. Za Zagrebačku nadbiskupiju intervjuirano je 15 vjeroučitelja/ica; 6 iz srednje i 7 iz osnovne škole; među njima su i dvije vjeroučiteljice iz Sisačke i Bjelovarske biskupije. U Splitsko-makarskoj nadbiskupiji intervjuirano je ukupno 8 vjeroučitelja/ica; 6 iz osnovne i 2 iz srednje škole, s time da jedan sudionik razgovora reprezentira Hvarsku biskupiju iz razloga što je tada imao 10 godina radnog iskustva u toj biskupiji, a živio je na području Splitsko-makarske nadbiskupije. Iz Đakovačke i srijemske nadbiskupije intervjuirano je 5 vjeroučitelja/ica ( 2 iz osnovne i 2 iz srednje škole) te jedan vjeroučitelj iz Požeške biskupije koji radi u srednjoj školi. Za Riječku metropoliju intervjuirano je ukupno 6 vjeroučitelja/ica, od kojih su 4 iz Riječke nadbiskupije (3 iz osnovne i 1 vjeroučiteljica iz srednje škole), zatim 1 vjeroučitelj iz Porečko-pulske i 1 vjeroučiteljica iz Gospićko-senjske nadbiskupije. Budući da Krčka biskupija ima najmanji broj vjeroučitelja/ica, reprezentativno je prisutna u Riječkoj metropoliji. U Zadarskoj nadbiskupiji te Šibenskoj i Dubrovačkoj biskupiji intervjuirano je ukupno 6 vjeroučitelja/ica, po 2 vjeroučitelja iz osnovne i 2 iz srednje škole. Iz Varaždinske biskupije u uzorak istraživanja bila je uključena samo jedna vjeroučiteljica. Cjelokupni

11 Usp. Marlene Bock, Das halbstrukturierte-leitfadenorientierte Tiefeninterview: Theorie und Praxis der Methode am Beispiel von Paarinterviews, u: Jürgen H. P. - Hoffmeyer-Zlotnik (ur.), Analyse verbaler Daten. Über den Umgang mit qualitativen Daten, Westdeutscher Verlag, Opladen, 1992.

12 Usp. Goran Milas, Istraživačke metode u psihologiji i drugim društvenim znanostima, 587. 
uzorak kvalitativnog istraživanja obuhvaća 24 vjeroučitelja/ice koji/ koje rade u osnovnim školama; od toga 13 vjeroučitelja/ica mlađe dobne skupine s radnim iskustvom od 2 do 9 godina te 11 vjeroučitelja/ica starije životne dobi s radnim iskustvom u školskom odgojno-obrazovnom sustavu od 10 do 19 godina. Vjeroučitelja/ica iz srednjih škola bilo je zastupljeno ukupno 17, od čega 8 vjeroučitelja/ica mlađe životne dobi, s radnim iskustvom do 9 godina staža, i 9 vjeroučitelja/ica starije životne dobi, s radnim iskustvom od 10 do 19 godina. Dobna skala vjeroučitelja obuhvaćala je godine života od 26 do 60, odnosno od 2 do 19 godina radnog staža. Sudionici razgovora su ravnomjerno raspoređeni, prema starosnoj dobi, godinama radnog staža i spolnoj određenosti, što su ujedno bile i istraživačke varijable kvalitativnog istraživanja. Prva faza istraživanja započeta je s pilot-istraživanjem koje je obuhvaćalo 6 sudionika razgovora na području Zagrebačke nadbiskupije: 3 vjeroučitelja iz osnovne i 3 iz srednje škole, koje je uvršteno u uzorak glavnog istraživanja. ${ }^{13}$

\section{SAKRAMENTI - SUSRETI S KRISTOM U CRKVI}

U promatranju sakramenata Crkve pod vidom otajstvenog susreta s Bogom po Kristu u Duhu, ${ }^{14}$ preko vidljivih znakova, zapažamo da u njima primarno dolazi do izražaja osobna dimenzija čovjeka vjernika, odnosno vjeroučitelja otvorenog milosnom Božjem učinku. S obzirom da susret kao spasenjski događaj ponajprije polazi od onog vidljivog i materijalnog te vodi prema nevidljivoj milosti, njegovo se ostvarenje događa $u$ dijalogu vjere i milosti, $u$ interakciji ljudskoga i božanskoga. Upravo u Crkvi, kao općem sakramentu spasenja, božansko se ujedinjuje s ljudskim te time sve ono što je ljudsko biva posvećeno božanskim. U tom duhu s pravom možemo ustvrditi da su sakramenti djelotvorni znakovi komunikacije s Bogom u kojima se događa otajstvo sakramenta, gdje čovjek govori snagom simbola i znakova u vjeri, a Bog progovara snagom milosti. Takav dijalog Boga i čovjeka postaje signum efficax na mnogostruku korist vjeroučitelja vjernika laika. ${ }^{15}$ Nadalje, taj susret ostaje uvi-

13 O raznolikosti metodoloških pristupa u kvalitetnom istraživanju, izabranom obliku intervjua, izboru uzorka, i provođenju intervjua više vidi u: Kata s. Amabilis Jurić, Duhovnost vjeroučitelja laika u Hrvatskoj, Zagreb, 2015., 235-242.

14 Naše promišljanje o sakramentima primarno se temelji na smjernicama nove teologije poimanja sakramenata poslije Drugoga vatikanskog koncila, na koji su posebno upućivali Edward Schillebeeckx, Karl Rahner i dr.

15 Usp. Niko Ikić, Prikaz knjige Ante Mateljana, Otajstvo susreta. Temeljna sakramentologija, recenzije, Bogoslovska smotra, 81 (2011.) 4, 1027-1029, ovdje 1029. 
jek otajstvo, često teško opisivo i protumačivo. Ipak, kao i ljudski susret tako i susret s Bogom ima svoje uobličenje, te svaki susret s Bogom možemo u širem značenju pojma nazvati sakramentalnom stvarnošću. ${ }^{16}$ U uvodnom dijelu svoje knjige A. Mateljan postavljajući pitanje zašto Otajstvo susreta, obrazlaže naslov ovako: „Zato što se ključ kršćanske vjere i teologije nalazi u osobnom susretu s Kristom, a sakramenti su ljudski, osobni i zajednički način tog otajstvenog spasenjskog susreta. Zato ih treba pravo razumjeti i živjeti sa zahvalnošću prema onom koji nam u svetim znakovima daruje predokus budućega zajedništva za koje smo stvoreni." ${ }^{17}$ U kontekstu promišljanja Crkva - sakrament Krista (temeljni sakrament), A. Mateljan govori o Crkvi kao sakramentu koji pretpostavlja razumijevanje sakramentalne strukture povijesti spasenja te vjeru u Krista kao vidljivo uprisutnjenje Boga u ljudsku povijest, ustvrđujući da se tek ako Crkva nastavlja Kristovo djelo spasenja u ljudskoj povijesti, može i na nju primijeniti kategorija sakramenta. ${ }^{18}$ Stoga su sakramenti Crkve konkretnost i vidljivost Božjeg spasenja, što praktično znači „da Krist i njegovo djelo spasenja ne ostaju puko sjećanje i ljudska uspomena, nego postaju prava sadašnjost”. ${ }^{19}$

\subsection{Sakrament pokore ili pomirenja}

Istražujući relevantnu literaturu o sakramentu pokore ili pomirenja (sacramentum paenitentiae ili sacramentum reconciliationis), koji zajedno sa sakramentom bolesničkog pomazanja spada u sakramente ozdravljenja, nailazimo na more sadržaja koji je nemoguće cjelovito obuhvati u ovome radu. ${ }^{20}$ Stoga se ograničavamo na kratak prikaz teološkog značenja ovog sakramenta za kršćanski život svakog kršćanina vjernika, pa prema tome i vjeroučitelja vjernika laika. Odmah na početku valja naglasiti da je ovaj sakrament doži-

16 Usp. Ante Mateljan, Svete tajne: navještaj „silnih djela Gospodnjih”, Diacovensia, 24 (2016.) 3, 351-362, ovdje 354.

17 Ante Mateljan, Otajstvo susreta. Temeljna sakramentologija, 8.

18 Usp. Isto, 64.

19 Edward Schillebeeckx, Krist sakrament susreta s Bogom, Kršćanska sadašnjost, Zagreb, ${ }^{21992 ., 37}$

20 Usp. Antun Tamarut, Da bismo imali udjela s Kristom. Izabrane teme iz sakramentalne teologije, Glas Koncila, Zagreb, 2009., 77-128; Niko Ikić, Teologija sakramenata. 'Gorući grm' sakramentalne milosti, 283-362; Ivan Karlić, Sveti sakramenti. Susret s Isusom Kristom u sakramentima, 139-186, Zvonko Pažin, Liturgijska sakramentologija, Katolički bogoslovni fakultet u Đakovu, Đakovo 2018., 157185; Carlo Collo, Riconciliazione e penitenza. Comprendere, vivere, celebrare, Edizioni San Paolo, Cinisello Balsamo (Milano), 1993. 
vio mnoge promjene, kao rijetko koji drugi, što potvrđuju i njegovi različiti nazivi, kao npr. sakrament ispovijedi, pokore, pokajanja, koji se nije udomaćio kao opći naziv, nego sakrament obraćenja ${ }^{21}$ i pomirenja, jer sakramentalno ostvaruje Isusov poziv na obraćenje (usp. Mk 1,15). Svi navedeni nazivi imaju parcijalno značenje, za razliku od naziva pomirenja, koje, shvaćeno kao proces, u najvećoj teološkoj mjeri dovoljno i snažno izražava kako dijelove, tako i cjelovitost procesa sakramentalnog pomirenja. ${ }^{22}$ Pojednostavnjeno rečeno, sakrament ispovijedi ili pomirenja i pokore jedan je od sedam svetih sakramenata u kojemu pokornik (grješnik) iskreno i s pokajanjem vlastite grijehe počinjene nakon krštenja očituje svećeniku koji ima vlast da ga od njih odriješi. Prema crkvenom poimanju utemeljitelj ovog sakramenta je sam Isus Krist, koji je nakon uskrsnuća rekao apostolima: „Primite Duha Svetoga. Kojima otpustite grijehe, otpuštaju im se, kojima zadržite, zadržani su im” (Iv 20,22-23). ${ }^{23}$ „Sva vrijednost Pokore jest u tome da u nama ponovno obnovi Božju milost i s Bogom nas sjedini dubokom ljubavlju. Svrha i učinak ovog sakramenta je, dakle, pomirenje s Bogom. Koji primaju sakrament pokore raskajana srca i s religioznim raspoloženjem, postižu mir i spokoj savjesti zajedno s jakom duhovnom utjehom. Sakrament pomirenja s Bogom donosi istinsko duhovno uskrsnuće, vraća dostojanstvo i dobra života djece Božje, od kojih je najdragocjenije Božje prijateljstvo". ${ }^{24}$ Iz navedenog teksta evidentno je da KKC jasno ukazuje na središnji cilj i svrhu sakramenta pokore i pomirenja, a to su oproštenje, pomirenje i mir te povratak u zajedništvo i prijateljstvo s Bogom. Osim toga mogli bismo reći da je na jedinstven način to i sakrament milosrđa u kojem se iskazuje Božja milosrdna ljubav koja oprašta, vraća izgubljeno dostojanstvo, miri s Bogom i Crkvom te daje snagu za nov početak. ${ }^{25}$ Bit sakramenta pomirenja/pokore sažeta je u riječima odrješenja koje prema popravljenom i dopunjenom izdanju Reda pokore glase: „Bog, Otac

21 U KKC također se navodi više naziva za ovaj sakrament. Novost je u tome što se odmah na početku govora o nazivu ovog sakramenta (br. 1423) ističe da se zove sakrament obraćenja, jer sakramentalno ostvaruje Isusov poziv na obraćenje (usp. Mk 1,15), put povratka k Ocu (usp. Lk 15,18).

22 Usp. Niko Ikić, Teologija sakramenata. 'Gorućigrm’ sakramentalne milosti, 283-284; o nazivima ovog sakramenta također vidi u: Ivan Karlić, Sveti sakramenti. Susret s Isusom Kristom u sakramentima Crkve, 141-143.

23 Usp. Mladen Parlov, Marulićevo poimanje sakramenta pokore i pomirenja, Colloquia Maruliana, XI (2002.), 95-107., ovdje 99-100.

24 KKC, br. 1468.

25 Usp. Davor Vuković, Odrješenje i pomirenje kao darovi Božje milosrdne ljubavi, Diacovensia 24 (2016.) 4, 555-566, ovdje 556. 
milosrđa, koji je smrću i uskrsnućem svojega Sina pomirio sa sobom svijet i izlio Duha Svetoga za otpuštenje grijeha, neka ti po službi Crkve udijeli oproštenje i mir. I ja te odrješujem od grijeha tvojih u ime Oca i Sina i Duha Svetoga." ${ }^{26}$ Pomirenje je naime neophodno jer je grijeh učinio razdor te donio nemir, zlo, podijeljenost među ljudima i u svijetu. Pomirenje je Božji dar i zahvat, čin Božje milosrdne ljubavi, ali je ujedno i zadaća i zadatak suvremenom čovjeku, jer „Bog u svojem milosrdu dolazi k nama, hrabri nas i daje nam snagu da uz njegovu pomoć izlazimo iz sebe, da se prestanemo egoistički pomirivati sa sobom, da naprotiv počnemo hrabro sebe mijenjati."27 U tom smislu pomirenje predstavlja i plod obraćenja, čovjekova truda; dakako, uvijek u svjetlu da je ono prije svega Božja inicijativa i čisti dar, koji uključuje čovjekovu suradnju te poziv na obraćenje i prihvaćanje pomirenja. ${ }^{28}$ Stoga su pomirenje i obraćenje međusobno neodjeljivo povezani.

Svrha i temeljni učinci sakramenta pomirenja su pomirenje s Bogom, sa samim sobom i sa svim stvorenjem. Svaki čovjek, utoliko više vjeroučitelj vjernik laik, koji s vjerom prima ovaj sakrament raskajana i čista srca, s prikladnim vjerskim raspoloženjem, postiže duhovni mir i umirivanje savjesti zajedno sa snažnom duhovnom utjehom, kao i rast duhovne snage za daljnju kršćansku borbu protiv zla i grijeha. ${ }^{29}$ Otajstvo pomirenja, odnosno sam sakrament pomirenja ima četiri važna vida, ${ }^{30}$ što je evidentno $u$ iskazima intervjuiranih vjeroučitelja/ica. U ovom otajstvu ponajprije se radi o pomirenju s Bogom, koje obnavlja narušeni mir i prijateljstvo s njim (vertikalni vid), no ono donosi i pomirenje čovjeka sa samim sobom, s Crkvom i u konačnici sa svim stvorenim (horizontalni vid). U tom duhu, plodovi i učinci sakramenta pomirenja jesu u pomirenju s Bogom, koje se očituje u obnavljanju mira i prijateljstva s njima, pomirenju $s$ Crkvom, gdje se događa ponovno uključivanje u zajedništvo svetih i pomirenju sa samim sobom, tako što se ponovno vraća narušeni mir u dubinama vlastitoga bića i otkrivanje istine o sebi.

26 Rimski obrednik, Red pokore, Zagreb, 2009.

27 Ivica Raguž, Milosrđe, Đakovo, 2015., 25.

28 Usp. Davor Vuković, Odrješenje i pomirenje kao darovi Božje milosrdne ljubavi, 557.

29 Usp. Ivan Karlić, Sveti sakramenti. Susret s Isusom Kristom u sakramentima Crkve, 169-170.

30 Više o tome vidi u: Kongregacija za kler, Svećenik - služitelj Božjega milosrđa, Kršćanska sadašnjost, Zagreb, 2014., br. 32; usp. Ivan Pavao II., Reconciliatio et paenitentia. Pomirenje i pokora, Kršćanska sadašnjost, Zagreb, 1996., br. 26, 31. 


\subsection{Sakrament euharistije}

U govoru o sakramentima kršćanske inicijacije $\mathrm{KKC}$ ističe da sakrament euharistije dovršava kršćansku inicijaciju, jer „oni naime koji su Krštenjem uzdignuti na dostojanstvo kraljevskog svećenstva te Krizmom dublje suobličeni Kristu, po Euharistiji s čitavom zajednicom sudjeluju u samoj Gospodinovoj žrtvi” (KKC 1212). Drugi vatikanski sabor naziva euharistiju ,izvorom i vrhuncem svega kršćanskog života”, ${ }^{31}$ iz razloga što su svi ostali sakramenti tijesno povezani s njom i prema njoj su usmjereni. ${ }^{32}$ Osim toga Euharistija je snaga „iz koje Crkva stalno živi i raste” (usp. LG 26). Razlog za takvo teološko vrednovanje nalazi svoje utemeljenje u samorazumijevanju Crkve, čiji se smisao sastoji u tome da je „znak i sredstvo najprisnijega sjedinjenja s Bogom i jedinstva cijeloga ljudskog roda" (LG 1). Iz ove tvrdnje evidentno je da se Crkva najjasnije očituje u slavlju svete euharistije i sve drugo njezino djelovanje pridodano je toj živoj i ujedinjavajućoj nazočnosti Kristovoj. ${ }^{33}$

Bogatstvo ovog sakramenta izražava se u različitosti njegova nazivlja: Euharistija - čin zahvaljivanja Bogu, riječi eucharistein (Lk 22,19; 1 Kor 11,24) i eulogein (Mt 26,26; Mk 14,22) podsjećaju na židovske blagoslovne molitve koje su se molile za objedom, a navješćuju čudesna Božja djela iskazana kroz stvaranje, otkupljenje i posvećenje; Gospodnja večera (usp. 1 Kor 11,20) - radi se o večeri koju je Gospodin Isus blagovao s učenicima u predvečerje svoje muke, kao i o predokusu svadbene gozbe Jaganjčeve (usp. Otk 19.9) u nebeskom Jeruzalemu; lomljenje kruha - obred koji je običavao vršiti Isus kada je kao predsjedatelj stola blagoslivljao i dijelio kruh (usp. Mt 14,19;15,36; Mk 8,6-9), posebno na Posljednjoj večeri (usp. Mt 26,26; 1 Kor 11,24); euharistijski sastanak ili zbor (synaxis) - ukoliko se euharistija slavi u zajednici vjernika, vidljivom izrazu Crkve (usp. 1 Kor 11,17-34); spomen-čin Gospodnje smrti i uskrsnuća; sveta žrtva ili sveta misna žrtva, žrtva zahvalna (Heb 13,15), duhouna žrtva (usp. 1 Pet 2,5), žrtva čista (usp. Mal 1, 11) i sveta jer je ispunjena i nadilazi sve žrtve Staroga saveza; sveta i božanska Liturgija - u njoj sva liturgija Crkve nalazi svoje središte i najzgusnutiji izraz te se stoga naziva i slavlje Svetih otajstava; pričest - u ovom se sakramentu sjedinjujemo s Kristom koji nas čini dionicima svoga Tijela i Krvi da s njim tvorimo samo jedno tijelo, naziva se

31 Drugi vatikanski koncil, Dogmatska konstitucija o Crkvi 'Lumen gentium', Krščanska sadašnjost, Zagreb, ${ }^{7} 2008 .$, br. 11., (dalje: LG).

32 Usp. KKC, br. 1324.

33 Usp. Franz Courth, Sakramenti. Priručnik za teološki studij i praksu, Forum bogoslova, Đakovo, 1997., 223-224. 
još i svetinja, svete tvari, ta hagia, sancta ili, prema Ignaciju Antiohijskom, kruh anđeoski, kruh nebeski, lijek besmrtnosti te popudbina...; Sveta Misa - liturgija u kojoj se ostvaruje otajstvo spasenja koje završava otpustom ili slanjem vjernika (missio) da ispune Božju volju u svakodnevnom životu. ${ }^{34}$

Spisi Novog zavjeta ustanovljenje euharistije povezuju s Isusovom pashalnom žrtvom, tj. njegovom smrću i uskrsnućem. Stoga govor o euharistiji treba povezati s povijesnim Isusom, s njegovim životom prije križa i uskrsnuća. U tom kontekstu naglašava se trostruki korijen euharistije: posljednja večera; zajednički bratski objedi o kojima govore novozavjetni spisi i zajednički objedi uskrsnulog Isusa Krista sa svojim učenicima. ${ }^{35} \mathrm{Za}$ cjelovitije razumijevanje događaja Posljednje večere treba uzeti u obzir povijesni kontekst židovske Pashe (pashalne večere), koja je bila višeslojna, tj. sadržavala je anamnezu, epiklezu, prinos, zahvalu i zajedništvo, ${ }^{36}$ gdje se mogu iskusiti osnovni kršćanski sadržaji euharistijske vjere. Kristova prisutnost u euharistiji, pretvorba i njezin zajedničarski karakter predstavljaju tri središnja teološka sadržaja euharistijskog događaja u odnosu na pashalnu večeru. Ne ulazeći dublje u teološko poimanje sakramenta euharistije, ${ }^{37}$ ovdje želimo poseban naglasak staviti na važnost euharistije za katehezu, jer u njoj vjeroučitelj dobiva novo smisaono usmjerenje za sebe i svoje vjeroučenike te biva pokristovljen. Upravo u euharistiji Kristov dolazak pod prilikama kruha i vina omogućuje vjeroučitelju vjerniku laiku osobitu bliskost s Bogom, gdje se događa preobražaj sebičnog čovjeka u Duhom ispunjeno dijete Božje, preobražaj mnogih pojedinaca u zajednicu braće i sestara koji se ljube. ${ }^{38}$ Tako euharistijska duhovnost ima odlučujuću ulogu u procesu prožimanja svakodnevnoga kršćanskog života euhari-

34 Usp. KKC, br. 1328-1332. O mnogostrukosti imenâ i različitosti njihovih vidika vidi također u: Franz Courth, Sakramenti. Priručnik za teološki studij i praksu, 229-232.

35 Više o ovoj problematici vidi u: Ivan Karlić, Sveti sakramenti. Susret s Isusom Kristom u sakramentima Crkve, 82-86.

36 KKC, br. 1350-1362; usp. također Zvonko Pažin, Liturgijska sakramentologija, 105, 122 i 124.

37 Za dublje proučavanje sakramenta euharistije vidi u: Ivan Karlić, Sveti sakramenti. Susret s Isusom Kristom u sakramentima Crkve, 79-137; Zvonko Pažin, Liturgijska sakramentologija, 77-146; Franz Courth, Sakramenti. Priručnik za teološki studij i praksu, 223-339; Anton Tamarut, Euharistija. Otajstvo vjere i dar Života, Glas Koncila, 2004.

38 Usp. Jadranka Garmaz - Martina Kraml, Živjeti od euharistije. Elementi euharistijske kateheze, Glas Koncila, Zagreb, 2010., 106-112. 
stijskim svjetlom, ${ }^{39}$ što se na poseban način odražava u djelovanju vjeroučiteljâ vjernikâ laikâ u Hrvatskoj. Nadalje, valja naglasiti da je unutarnja punina onoga što se u sakramentu euharistije događa mnogostruka, a može se iskazati sljedećim elementima: misterij apsolutne Božje blizine, tajna Krista, sakrament njegove smrti, žrtva njegove Crkve, snaga života, sveza jedinstva i ljubavi, oproštenje svakodnevne grešnosti, navještaj vječnoga života, predokus vječnosti, novi i vječni savez Boga i stvorenja, događaj nježnoga susreta srca s Bogom srca, prihvaćanje života i smrti. ${ }^{40}$ Za papu Benedikta XVI. euharistija je pak sakrament Boga koji je ljubav, prema enciklici Deus caritas est - Bog je ljubav $^{41}$ i prema postsinodalnoj pobudnici Sacramentum caritatis - Sakrament ljubavi. ${ }^{42}$ Upravo u toj darovnoj ljubavi Božjoj vjeroučitelji crpe snagu za svoje kršćansko djelovanje i nošeni Duhom Svetim „trče i ne sustaju, hode i ne more se” (Iz 40,31).

\subsection{Sakrament ženidbe}

U promišljanju o sakramentu ženidbe valja odmah na početku ustvrditi da nema ni jednog kršćanskog životnog područja koje je tako neposredno vezano uz djelokrug kršćanskog života i djelovanja kao što je područje vjernika laika, u našem slučaju vjeroučitelja vjernika laika. Prema KKC-u koncizno se daje do znanja da se „Ženidbenim savezom muškarac i žena vezuju u prisno zajedništvo života i ljubavi. Bog otac zasnovao je ženidbu i vlastitim je zakonima opskrbio. Po svojoj naravi ženidba je određena za dobro ženidbenih drugova i za rađanje i odgoj djece. Među krštenima Krist Gospodin uzdignuo je ženidbu na dostojanstvo sakramenta”. ${ }^{43} \mathrm{Na}$ pitanje ustanove braka kategorički odgovara Drugi vatikanski koncil riječima: „Intimna zajednica bračnog života i bračne ljubavi, koju

39 Usp. Matthias Scharer - Jozef Niewiadomski, Faszinierendes Geheimnis. Neue Zugänge zur Eucharistie in Familie, Schule und Gemeinde, Tyrolia, InnsbruckMainz, 1999., 131.

40 Usp. Karl Rahner, Die siebenfältige Gabe: über die Sakramente der Kirche, Ars sacra, München, 1974., citirano prema Dieter Emeis - Karl Heinz Schmitt, Grundkurs Sakramentenkatechese, Herder, Freiburg, 1980, 119.

41 Usp. Benedikt XVI., Deus caritas est. Bog je ljubav. Enciklika biskupima, prezbiterima i đakonima, posvećenim osobama i svim vjernicima laicima o kršćanskoj ljubavi, Kršćanska sadašnjost, Zagreb, 2016., br. 13.

42 Usp. Benedikt XVI., Sacramentum caritatis. Sakrament ljubavi. Postsinodalna apostolska pobudnica Svetoga Oca Benedikta XVI. o euharistiji, izvoru i vrhuncu života i poslanju Crkve, upućena biskupima, kleru i osobama posvećenog života i vjernicima laicima, Kršćanska sadašnjost, Zagreb, 22008., br. 94.

43 KKC, br. 1660. 
je Stvoritelj utemeljio i providio vlastitim zakonima, uspostavlja se ženidbenim savezom, odnosno neopozivom osobnom privolom. Tako po ljudskom činu kojim se supruzi uzajamno predaju i primaju, nastaje - također pred društvom - po božanskoj uredbi čvrsta ustanova. Ta sveta veza u vidu dobra ženidbenih drugova, potomstva i društva ne ovisi o ljudskoj samovolji. Sam je, naime, Bog začetnik ženidbe, koja je proviđena različitim dobrima i svrhama”. ${ }^{44}$ Neki stari crkveni oci govorili su o ustanovljenu sakramenta ženidbe na svadbi u Kani (usp. Iv 2,1-12). U tom se kontekstu u KKC-u navodi: „Na početku svog javnog djelovanja Isus je - na zahtjev svoje majke - učinio svoje prvo čudo za vrijeme jedne svadbe. Crkva pridaje veliku važnost Isusovoj nazočnosti na svadbi u Kani. U tome prepoznaje potvrdu da je ženidba nešto dobro i navještaj da će odsad biti djelotvornim znakom Kristove nazočnosti." 45

Kršćansko shvaćanje sakramenta ženidbe, odnosno braka i obitelji ima svoje polazište i temelj u Bogu koji se tijekom povijesti objavio kao ljubav, kao onaj koji živi u prijateljskom zajedništvu Oca i Sina i Duha Svetoga. Stavlja se u neposrednu vezu s poimanjima braka u Starom zavjetu, što je evidentno iz prvih poglavlja Knjige Postanka (usp. Post 1, 26-28; 2, 18-25). Upravo to ljudsko zajedništvo muža i žene Bog izabire kao povlašteno mjesto svoje nazočnosti u svijetu po kojem nastavlja svoje djelo stvaranja i uzdržavanja svijeta. ${ }^{46}$ Budući da je struktura braka u Starom zavjetu prvotno bila određena potrebom osiguranja potomstva, ponekad je bila dopuštena određena vrsta bigamije ili poligamije te tzv. „usporedni brak“ s ropkinjom (usp. Izl 21,7-11; Pnz 21,10-15). Brak je bio razrješiv, a mogao ga je razriješiti samo muž, što govori o veoma teškom položaju žene u starom Izraelu. Novi zavjet preuzima starozavjetnu strukturu i shvaćanje ženidbe, ali joj daje nove naglaske, odnosno novi smisao bračnog saveza, koji se ispunjava otajstvom Isusa Krista. ${ }^{47} \mathrm{Na}$ Isusovim se riječima temelji kršćanski nauk o nerazrješivosti monogamijskog braka. To je evidentno u prepirci s farizejima (usp. Mk 10,1-12; Mt 19,3-9), gdje Isus produbljuje židovsko, odnosno starozavjetno

44 Drugi Vatikanski sabor, Pastoralna konstitucija o Crkvi u suvremenom svijetu 'Gaudium et spes', Kršćanska sadašnjost, Zagreb, ${ }^{72008 ., ~ b r . ~} 48$.

45 KKC, br. 1613.

46 Usp. Ivan Karlić, Sveti sakramenti. Susret s Isusom Kristom u sakramentima Crkve, 197.

47 Usp. Ivan Dugandžić, Ženidba u svjetlu Biblije, Bogoslovska smotra, 49 (1979.) 1-2, 6-19., ovdje 6-8; Niko Ikić, Teologija sakramenata. 'Gorući grm sakramentalne milosti, 446-451; Ivan Antunović, Sakrament ženidbe, Obnovljeni život, 65 (2010.) 1, 63-125. 
poimanje braka time što izjavljuje kako nije dopušteno „otpuštanje žene“, jer se protivi temeljnom shvaćanju braka kako je zapisano u već spomenutom izvješću o stvaranju, u kojem je, prema Božjoj zamisli, brak neprekinuto „biti jedno“ muža i žene. Daljnja tumačenja Matejeva evanđelja u raspravi s farizejima završavaju činjenicom da ih nije moguće tumačiti kao izuzetak zbog izričite Isusove zapovijedi o braku kao božanskoj ustanovi. O nerazrješivosti braka piše sveti Pavao, apostol narodâ, pozivajući se na Gospodinovu zapovijed; ovdje se radi o najstarijem novozavjetnom tekstu o nerazrješivosti braka (usp. 1 Kor 10-11; Rim 7, 2-3). Osim navedenog Pavao navodi i druga mjesta u Novom zavjetu koja se odnose na brak i ženidbu (usp. 1 Sol 4,3-8; 1 Kor 7,1-16; Ef 5, 21-33; 1 Kor 7, 12-16) u kojima odnos muža i žene apostol uspoređuje s odnosom Krista i Crkve: Kristova nadnaravna ljubav prema Crkvi postaje prisutna u naravnoj zajednici muža i žene, jednakopravnih partnera koji se trebaju podložiti Isusu Kristu. ${ }^{48}$ Promišljajući o kršćanskom pogledu na brak i obitelj, A. Tamarut iznosi osnovne značajke kršćanske ženidbe, koje se sastoje u prihvaćanju punom ljubavi (prihvaćanje i zajedništvo), djelatnom znaku Božje ljubavi (Isusov odnos s Crkvom); znaku vjere u Boga, izvor i obzor ljubavi (pouzdanje u Boga daje braku dubinu i čvrstoću), uzornom znaku gdje se aludira na novozavjetno mjesto Poslanice Efežanima 5, 25-26, na kojem se temelji kršćanski nauk o sakramentalnosti ženidbe. ${ }^{49}$

Valja na kraju naglasiti da je osnovna crta cjelokupnoga novozavjetnog govora o ženidbi njegova kristocentričnost, jer je čitava novozavjetna spasenjska stvarnost uronjena u Krista i na njemu počiva, što je najjasnije izraženo u Ef 5, 22-32. ${ }^{50}$ Stoga zaključno možemo ustvrditi da „svaki put kad supružnici stvarno žive tjelesne, obiteljske i društvene posljedice ženidbene milosti, oni pokazuju jednostrano mističan, međuosoban i privatni pogled na religioznost koji podupire različite oblike podređenosti te naviješta sklad kakav je htio Isus između duše i tijela, čovjeka i žene, roditelja i djece zaljubljenih i neželjenih". ${ }^{51}$

48 Iscrpnije o novozavjetnom govoru o ženidbi vidi u: Ivan Karlić, Sveti sakramenti. Susret s Isusom Kristom u sakramentima Crkve, 251-290.

49 Usp. Antun Tamarut, Da bismo imali udjela s Kristom. Izabrane teme iz sakramentalne teologije, 200-209.

50 Usp. Ivan Dugandžić, Ženidba u svjetlu Biblije, 15.

51 Philip J. Rosato, Introduzine alla teologia dei sacramenti, Edizioni Piemme, Casale Monteferrato (Al), 1992., 102. 


\section{KONKRETNA OČITOVANJA SAKRAMENTALNE DUHOVNOSTI VJEROUČITELJA U KVALITATIVNOM ISTRAŽIVANJU}

Uvodno treba naglasiti da je prethodno memorirani upitnik korišten u kvalitativnom istraživanju bio koncipiran od deset opširnih pitanja, kasnije u analizi rezultata grupiranih u tri tematska područja. Jedno od navedenih pitanja odnosilo se na očitovanje konkretnih načina u ostvarenju duhovnosti vjeroučitelja u svakodnevnom životu. ${ }^{52}$ Iz raznolikih načina u kojima se konkretno očituje duhovnost vjeroučitelja laika, posebnu su pozornost plijenili izričaji o njihovom sakramentalnom životu u sakramentima pomirenja, euharistije i braka.

\subsection{Sakrament pomirenja kao proces odgajanja, rasta i povjerenja u Boga ljubavi}

S obzirom da kvalitativna istraživanja nude bogat spektar raznih informacija, ovdje koristimo samo neke od iskaza vjeroučitelja/ica ${ }^{53}$ koji su pripovijedali o svojim iskustvima u odnosu na sakrament pomirenja, percipirajući ga kao proces duhovnoga odgajanja, rasta te istinskog povjerenja u Boga ljubavi i dobrote. U tom kontekstu jedna mlada vjeroučiteljica u svom iskazu ističe:

„Sakrament ispovijedi je za mene pokazatelj kako je Bog prema čovjeku dobar. Mnogi kažu Krist da, Crkva ne, što ću se ispovijedati tom nekom svećeniku, ja sebi nisam nikada postavljala takva pitanja, ja tu osjećam olakšanje, slobodu, novi početak, u kajanju da neću više to činiti, a to je ono moje unutarnje opredjeljenje, a naša narav je sklona grijehu, ne smijemo se naviknuti na grijeh i ne smijem postati imuna na grijeh... Kad Bog oprosti grijeh onda se osjećam sretnom i zadovoljnom, tu je i ona spoznaja mogu učiniti ne znam što ali znam da me moj Bog voli unatoč svemu i ja sam uvijek njegovo ljubljeno dijete i tu mi se ponovno oživljava ona slika Oca, tko će mi više pomoći ako se bilo što dogodi ako ne Otac i Majka? (to je tako izgovarala sa uvjerenjem, radosno i punim srcem). Treba čovjek imati ritam $u$ ispovijedanju izvan onoga što Crkva savjetuje, moj ritam je pred velike blagdane ili barem u dva

52 O načinu provođenja intervjua iscrpnije vidi u: Kata s. Amabilis Jurić, Duhounost vjeroučitelja laika u Hrvatskoj, 240-242.

53 Cjelokupna dokumentacija o intervjuima nalazi se na DVD-u priloženom u džepu unutarnjeg dijela desne strane doktorskog rada u Sveučilišnoj knjižnici. Usp. Kata s. Amabilis Jurić, Duhovnost vjeroučitelja vjernika laika u suvremenim hrvatskim crkveno-društvenim uvjetima. Doktorski rad, Zagreb, 2013. 
mjeseca, ako se ne ispovijedam onda postajem imuna na grijeh, i nekako se hladim i udaljujem od Boga" (P. P., 28). ${ }^{54}$

Na istome tragu je i hvalevrijedno promišljanje vjeroučitelja koji radi u srednjoj školi:

„Sakrament ispovijedi mi je jako važan... Za mene ovaj sakrament znači nešto kao tuširanje, čišćenje, oslobađanje i poslije toga osjećam neizmjernu radost i sreću da skoro skačem od sreće jer mogu nanovo početi. Na početku svog obraćenja sam tražio duhovni razgovor i bio sam ljut ako se svećenik nije posvetio meni, međutim sada mi je dovoljno da se istuširam i to što prije i ne smeta mi koji je svećenik jer vrednujem sakrament kao takav" (I. B., 35). ${ }^{55}$

O davanju prednosti odgojnoj pred teoretskom dimenzijom sakramenta pomirenja svjedoči sljedeći iskaz:

„Glede sakramenta ispovijedi važna mi je ta odgojna dimenzija više nego taj teorijski sakramentalni vid sakramenta pomirenja. To ne želim niti djeci tako tumačiti nego više evo idem se ja sada malo spustiti dolje, nisam to što možda drugi govore ili mislim da jesam, slab sam, nikakav sam, ništavan sam, običan sam i takav doći pred Boga (nasmijao se). Bože takav sam, evo priznajem da sam takav. Dakle ta jedna odgojna dimenzija ispovijedi meni u praksi više znači nego neko sakramentalno teoretiziranje, jednostavno da se čovjek ponizi i kaže da je čovjek slab, Bože takav sam i pomozi mi!" (I. K., 37). ${ }^{56}$

Iz iskaza vjeroučitelja starije životne dobi evidentna je činjenica stanovite zrelosti u poimanju sakramenta pomirenja:

„Sakrament svete ispovijedi to je tako postalo nešto prirodno isto kao kad bi čovjeka pitao je li se ti umiješ svako jutro? (tu se je nasmijao izričući ugodnije je ipak kad se umijemo). S druge strane vidim opet jedan izraz ljubavi u tom darivanju oproštenja, doživim jedan osmijeh Isusov prema meni; da, da unatoč grijesima osmijeh, a s druge strane vidim da moram paziti da se ni u čemu ne umislim. Ja bih mogao svaki treći dan otići na ispovijed, drugim riječima ovaj me sakrament vježba u poniznosti, relaksira me, osvježava me itd. tako da na ispovijed ne gledam nikada kao na neku obvezu, nego jedan od susreta s Gospodinom i pokušavam to živjeti, normalno da se može i više i bolje i unatoč slabostima kretati uvijek ispočetka, jer ako ne možeš krenuti ispočetka onda

$54 \quad$ Isto, Intervju br. 36.

55 Isto, Intervju br. 29.

56 Isto, Intervju br. 12. 
nećeš nigdje ni stići. Zato je sakrament svete ispovijedi uvijek taj novi početak" (B. B., 60). ${ }^{57}$

Kad se u teološko-katehetskoj literaturi govori o važnosti sakramenta pomirenja za vjeroučiteljev život i poslanje, primjećuje se kako je on danas došao u krizu zbog opasnosti individualizma kao i gubljenja kompletnog osjećaja za grijeh. ${ }^{58}$ Nasuprot tomu iskazi, ne samo ovdje navedenih intervjuiranih vjeroučitelja, nego i ostalih koji su bili obuhvaćeni kvalitativnim istraživanjem, ukazuju na činjenicu da je ovaj sakrament za njih pravi izvor iz kojega crpe snagu za novi život u Kristu i konkretnom djelovanju bilo da se radi o školi ili župnoj zajednici. To ne znači da možemo zanemariti činjenicu kako se ti isti vjeroučitelji ne susreću s poteškoćama glede ovog sakramenta, što se primarno odnosi na vjeroučitelje mlađe životne dobi, koji ovaj sakrament doživljavaju kao odgojni proces rasta i napredovanja u njihovom duhovnom životu. Intervjuirani vjeroučitelji starije životne dobi ovaj sakrament doživljavaju daleko zrelije i temeljitije, za razliku od vjeroučitelja mlađe životne dobi, koji na tom putu još uvijek trebaju rasti i napredovati.

\subsection{Sakrament euharistije kao otajstvo susreta sa živim Bogom}

Glede percipiranja ovog sakramenta posebnu pozornost zavrjeđuju iskazi vjeroučitelja mlađe životne dobi koji redovito odlaze na euharistijsko slavlje jer ga doživljavaju kao susret sa živim Bogom koji ih ispunja Duhom Svetim, Božjom riječju, rasterećenjem, i vraća ih obnovljenom snagom u svakodnevni život. Unatoč nemogućnosti potpunijeg razumijevanja otajstvenog događanja u euharistijskom slavlju, ipak ga jedna mlada vjeroučiteljica doživljava uvijek na nov način:

„Euharistija u mom duhovnom životu je najvažnija. I opet nakon fakulteta što sam ja shvatila što zapravo sakrament znači, da je to nešto živo a ne samo neka puka teorija ili samo neki nejasni obred. Svaku nedjelju idem na misu i nekada kroz tjedan, ovisno u kojoj crkvi, doživljavam misu različito i ono od sv. Tome: Vid $i$ opip okus, varaju se tu, al za čvrstu vjeru dosta je što čuh. Opet su tu nejasnoće i neka sumnja i tu također trebam dozrijevati u svojoj vjeri prema tom tako velikom misteriju. I uvijek je to spoznanje različito; nekad osjećaš tu milost a nekad ne osjetiš. Jednom sam

$57 \quad$ Isto, Intervju br. 28.

58 Usp. Pietro Damu, La spiritualità del catechista. Tracce per la riflessione personale e di gruppo sui tratti che la caratterizzano, ELLE DI CI, Leumann (Torino), 1997., 123. 
o tome razgovarala sa svećenikom koji mi je rekao kako bi to bilo da ti Bog daje svaki put milost, onda bi se ti uzoholila, milost ti se daje jednom pa da ti dalje čezneš još više za njim i da mu se još više otvaraš. Onda bi to postala rutina i ne bi znala to više ispravno cijeniti i onda stvarno shvatiš: tako je i s ljubavlju i s poštovanjem, iskrenošću, i sa svim ostalim vrednotama, ali uvije onak' zašto nije ko' prošli put?" (K. Ć., 27) ${ }^{59}$

Zadivljuje činjenica mlade vjeroučiteljice koja svakodnevno sudjeluje na euharistijskom slavlju, u kojem se događa najdublje sjedinjenje i darivanje:

„Euharistija je za mene središte kršćanskog života, svi znaju reći da nisam normalna jer idem svaki dan na svetu misu. Neka govore što hoće, meni to ne smeta, jer je euharistija za mene najdublji susret $\mathrm{s}$ Isusom Kristom i tu se $u$ najpotpunije $s$ njime sjedinjujem i tu mi se on u najpotpunijem smislu dariva, Bog se sam nama daruje $\mathrm{u}$ toj maloj hostiji, otajstvo je to veliko i nedohvatljivo, važno mi je to zato ako primam živoga Krista, ja primam njegovu snagu, njegovu djelotvornost, njegovu ljubav i sve ono što s njim ide u paketu i ojačana svime tim ja Boga nosim svuda kamo idem i da se to vidi i kako je lijepo zapravo biti njegov i to je ta duhovna hrana u meni i to je živi Krist u meni. Otići na misu a ne primiti Isusa za mene znači kao sjesti u auto a ne upaliti motor" (P. P., 28). ${ }^{60}$

Vjeroučiteljica koja radi u srednjoj školi u sakramentalno slavlje uključuje i svoje vjeroučenike:

„Što se tiče sakramenta euharistije ja bih prvenstveno rekla da se taj sakrament danas ne shvaća ozbiljno, a za mene je on važan zato što nam je Krist tu prisutan i daruje nam se pod prilikama kruha i vina. Na misu idem svake nedjelje i srijedom znam otići na misu i na klanjanje. Molitva kod kuće i misa su za mene različite i ako je crkva njegova kuća onda je idem svom prijatelju, ne kažem da nije kod moje kuće kad sama molim tu, ali gdje su dvojica ili trojica u moje ime ... Idem ja k njemu donosim mu i brige i probleme, zahvale i školsku djecu i sve što me muči i vraćam se kao kad se vraćate iz gostiju puna kući: ispunjena Božjom riječju, Duhom Svetim, samim Bogom i lakša i rasterećenija i u svakom slučaju punija i idem tako ponovno u svakodnevni život” (V. Ž. V., 29). ${ }^{61}$

Iz iskaza intervjuiranih vjeroučitelja mlađe životne dobi može se implicitno ustvrditi da u odnosu na ovaj sakrament osjećaju sta-

59 Kata s. Amabilis Jurić, Duhounost vjeroučitelja vjernika laika u suvremenim hrvatskim crkveno-društvenim uvjetima, Intervju br. 37.

$60 \quad$ Isto, Intervju br. 36.

61 Isto, Intervju br. 34. 
novite poteškoće, jer njihovi kolege ne dijele isto mišljenje s njima, sami osjećaju dubinsku potrebu za sakramentom euharistije koja im omogućuje da, unatoč svojim slabostima, mogu sve izdržati te tako napredovati u svojoj duhovnosti. Osim toga velika većina njih naglašava važnost komunitarne dimenzije euharistijskog slavlja, čime potvrđuju važnost promicanja duhovnosti zajedništva kao odgojnog načela, koje papa Ivan Pavao II. želi za cijelu Crkvu, ${ }^{62}$ a koje njima nedostaje.

Hvalevrijedni su iskazi intervjuiranih vjeroučitelja starije životne dobi, za koje euharistija zauzima središnje mjesto iz kojega crpe snagu za svakodnevni općeljudski i vjeroučiteljski život bez koje bi on za njih bio nezamisliv te time potvrđuju teološka promišljanja o sakramentu euharistije, kao i katolički nauk sadržan u dokumentima Crkve. Euharistija za njih nije samo obveza nego radost i životna potreba te s razlogom zauzima prvo i najvažnije mjesto u njihovu životu. Nadalje, u njihovim se iskazima zapaža slavljenje euharistije u nutarnjoj sabranosti i radosti kroz sve dublje uranjanje u neizrecivost otajstvenog događaja. Stoga je razumljivo da vjeroučitelji svetu misu doživljavaju kao životnu potrebu i spasenjski događaj, susret s onim kojeg ljube, odnosno trenutak jedinstva Krista i Crkve u kojoj doživljavaju svoje osobno sjedinjenje s njim, nutarnje ispunjenje koje rezultira sve većim Kristovim rastom $\mathrm{u}$ njima kroz njegovo umanjenje. Zbog prostornog ograničenja nismo u mogućnosti ovdje navesti sve te izričaje, stoga upućujemo na bazu podataka pohranjenu na već spomenutom CD-u koji se nalazi u Sveučilišnoj knjižnici u Zagrebu.

\subsection{Sakrament braka - znak Božje prisutnosti i autentičnosti Života}

U kvalitativnom istraživanju na poseban način privlači pozornost iskreno, iscrpno i krajnje spontano pripovijedanje o predbračnom životu i sakramentu ženidbe neovisno o tome jesu li intervjuirani vjeroučitelji oženjeni ili neoženjeni ljudi, premda se postavljeno pitanje nije izravno odnosilo na tematiku braka o kojoj su se izjašnjavali. ${ }^{63}$ Među intervjuiranim vjeroučiteljima mlađe dob-

62 Usp. Ivan Pavao II., Novo millennio ineunte. Ulaskom u novo tisućljeće. Apostolsko pismo episkopatu, kleru i vjernicima na završetku Velikoga jubileja godine 2000., Kršćanska sadašnjost, Zagreb, 2001., br. 43.

63 U kvalitativnim istraživanjima naglasak se stavlja na proučavanje fenomena $\mathrm{u}$ njihovu prirodnom okruženju, nastojeći im dati smisao i protumačiti ih sukladno značenju koje im pridaju vjeroučitelji/ice s kojima se provodi istraživanje. Budući da se radi o čuvstveno zasićenim pitanjima, pristup je daleko slobodniji i nije 
ne skupine izdvajamo pripovijedanje jedne sudionice razgovora $\mathrm{u}$ kojemu se mogu prepoznati gotovo sve bitne odrednice vjeroučiteljeva poimanja života prije braka, kao i samog sakramenta ženidbe, odnosno braka opisanog u prethodnim teorijskim promišljanjima:

„Glede sakramenta braka, života prije braka i obiteljskog života, nadam se da ću biti vjerodostojna s obzirom da nisam udata. Za mene je taj predbračni život važan, jer postoji Božji zakon, a taj je da treba čisto hodati prije braka. Predbračni život ne prihvaćam samo radi toga što mi to Crkva preporuča, nego jer je to za mene jedno veliko otajstvo puno mudrosti i plemenitosti, i da nisam u vjeri vjerojatno to ne bi niti tako shvaćala. No, budući da vjerujem, takav način života je za mene nešto sasvim normalno i uzvišeno, dok je mojim vjeroučenicima to naprosto neshvatljivo. Stoga me gledaju s čuđenjem i ne mogu to jednostavno pojmiti te misle da sam ja jedna naprema sto, dvjesto koja to može. Za većinu ili gotovo sve moje kolege vjeroučitelje, to je nešto što je staromodno, nisi cool, kako često znam čuti, prezahtjevna zadaća, i ne može dvoje ljudi koji se vole tako živjeti. Unatoč svemu tome neshvaćanju moji mi vjeroučenici vjeruju, i to mi puno znači. Ja ne poštujem predbračni život samo zato što sam vjernica ili vjeroučiteljica, nego meni je to osobno kao ženi jako važno. Prvenstveno je tu bitno poštivanje sebe, jer ako vi ne poštujete sebe, ne možete očekivati da vas druga osoba poštuje. Ako toga nema, druga će osoba uzimati sve zdravo za gotovo, vidjet će da je sve lako postigla i neće osjetiti nikakav izazov, ništa neće naučiti, i na kraju vas neće ni cijeniti, nego će vas upravo radi toga kasnije početi opterećivati, kritizirati, omalovažavati i tomu sl. Moram priznati da nije lako naći pravog suputnika, bolje je i pet godina $\mathrm{u}$ kvalitetnome braku, nego dvadeset godina $\mathrm{u}$ bilo kakvome drugom. Što se tiče mog izbora prvoga momka, sve je to skupa bilo nedavno. Ipak sam bila zrela, ali mislim da sam možda i previše bila lakomislena, da sam previše poletjela u nebesa. Kad već nije uspjelo kod mog izbora prvoga mladića, predala sam se Bogu na raspolaganje i osluškivanje da vidim kojeg će mi on poslati. Jednom prilikom je jedan svećenik za vrijeme propovijedi preporučio da molimo jednu deseticu krunice za svoga budućeg zaručnika, tako da sam nedavno počela moliti,

standardiziran, a od voditelja razgovora očekuje se posjedovanje izuzetne vještine poticanja sugovornika kako bi se o osjetljivoj temi mogao slobodno izjašnjavati bez komunikacijskih zapreka, što je i evidentno u vjeroučiteljskim iskazima. Usp. Goran Milas, Istraživačke metode u psihologiji i drugim društvenim znanostima, 572 i 587. 
(Tu se od srca nasmijala i na mene ostavila takav dojam kao da je budući zaručnik već tu) i ja vjerujem da će mi to Bog ostvariti, jer ja želim biti žena i majka, ja ga već imam, samo ga trebam otkriti i prepoznati” (A. K, 27, 3). ${ }^{64}$

Premda gore navedeno promišljanje na prvi pogled može izgledati odveć idealno, ipak moramo priznati istinitost njegova iskaza te zatečenost pred otvorenošću, spontanošću i iskrenošću pripovijedanja ne samo navedene sudionice razgovora nego i iskaza ostalih mladih vjeroučitelja, koji su bez imalo ustručavanja pripovijedali o svojim najdubljim iskustvima na tom području. Da je tomu tako, potvrđuje jedno drugo promišljanje i iskustvo mlade intervjuirane vjeroučiteljice, koja je duboko svjesna da mladi vjeroučitelji danas žive integrirani u konkretnom društvu sa svim njegovim prednostima i nedostacima, te da predbračni i bračni život vjeroučitelja ne treba biti u stilu današnje propagande, nego se treba temeljiti na sakramentalnim vrijednostima:

„Predbračni život vjeroučitelja treba biti ne u stilu ovoga što se danas propagira, nego treba imati na pameti vrijednost čovjeka kao takvog. Bog uvijek stavlja osobu u prvi plan i svakoj se osobi obraća s poštovanjem. Kad kažem osoba, onda govorim o nerazdvojnoj cjelini tijela, psihe i duha, te ne smijemo jednomu davati prednost na štetu drugoga. Znači ako je osoba zrela i razumije što su vrijednosti i zalaže se da živi svoj život u punini, onda nema problema. Mi mladi vjeroučitelji ne živimo pod staklenim zvonom. Zalažem se zato da predbračna, pa čak i bračna, čistoća bude cilj sazrijevanja dvaju mladih bića. Nažalost, imam prijatelja koji prebrzo te neke stvari napuste, a onda se gotovo cijeli život kaju... Crkva ništa ne zapovijeda, nego samo nudi kao izbor za naše dobro, jer joj je prvenstveno stalo do čovjeka. Ona je zapravo taj moralni stup, jer neki ljudi ne znaju pravo odlučiti za sebe, stoga im samo daje upute kako živjeti. Za mene se tu prvenstveno radi o dostojanstvu same osobe, ja sam to slobodno izabrala na temelju razuma, odgoja, kao i svega onoga kako se u sebi konkretno osjećam. Smatram da u sebi imam klicu dobra koju trebam njegovati da raste, i da ja najbolje znam što meni odgovara ili ne, a ne da se povodim za pomodarstvom u stvarima koje svima odgovaraju pa će onda i meni. To činim zato što drugi ne mogu živjeti moj život i moje osjećaje, pa tako ne mogu ni ja prihvatiti to što je drugima sasvim normalno i prihvatljivo. Tu prvenstveno gledam na dostojanstvo žene, koje je svima nama darovano... Time ne tražim da žena bude zatvorena, ali se ipak trebaju znati vrijednosti, a za mene pornografija nije vrijednost. Ako se vladam u duhu ovoga vremena, onda ne živim

64 Kata s. Amabilis Jurić, Duhounost vjeroučitelja vjernika laika u suvremenim hrvatskim crkveno-društvenim uvjetima, Intervju br. 32. 
u skladu s vjerom i sa sobom i na taj način zapravo sebe ponižavam i pokazujem što ja mislim o sebi. Tu su također dodatni problem i majke koje pružaju krivi primjer svojoj djeci, jer nemaju taj osjećaj da misle na druge, nego na sebe same. Drugim riječima, žena je danas postala egoistična, i zato nije sposobna za istinsko darivanje" (K. R, 27, 3). ${ }^{65}$

O tome kako skladno bračno zajedništvo, odnosno duhovnost koja iz njega proizlazi pomaže vjeroučitelju u njegovu autentičnom svjedočenju pred učenicima, svjedoči sudionik razgovora koji radi u srednjoj školi:

„Brak je nešto novo u životu, i to je još jedan novi način gdje mi Bog kaže da je prisutan u mom životu. Ta se Božja prisutnost u sakramentu braka očituje kroz jednu novu vrstu zajedništva, kroz spremnost na praštanje... U takvim stanjima vidiš da se treba nekad malo i poniziti, doći u situaciju da shvatiš kako je tu zapravo duh Božji na djelu, upravo onda kada potiče ili jednoga ili drugoga bračnog druga na to iskreno praštanje, koje u sebi uključuje ono: poštivat ću te i ostati s tobom kako u dobru tako i u zlu. Tim sakramentalnim činom kao da je stavljen neki štit na supružnike, koji kroz taj i ostale sakramente ne dopušta zlome da ima previše utjecaja na razaranje stvorenog bračnog zajedništva. Čini mi se da je najprije potrebno osloboditi se nekih zarobljenosti ili klišeja koje u sebi nosimo kao posljedice krivog odgoja. Recimo, kad gledam sebe i svoju ženu u tome svemu, baš je to taj dio koji nedostaje. Koliko je drugačija od mene i po naravi i po vanjštini, po tome što je žena, zapravo, baš kao da ju je Bog tako osmislio, pa da je čovjek uskliknuo: „evo kosti od mojih kostiju, mesa od mesa mojega, ženom neka se zove od čovjeka kad je uzeta!” Bog je znači u tom stvaranju Adama i Eve vidio mene i moju ženu, i već nas je tad, hajdemo reći, spojio i učinio da se na životnom putu sretnemo. Veliko je to otajstvo, tajna u kojoj se stalno isprepliće ono ljudsko i božansko. Sada je meni ta sakramentalna otpečaćenost samo znak da je Bog na još jedan posebniji način prisutan, i uvijek se iznova u životu pokazuje prisutnim u našem bračno-obiteljskom zajedništvu. U vremenima krize se upravo očituje ta Božja vjernost nama, a i moja vjernost Bogu, koja je identična s onom vjernošću prema mojoj ženi koju sam izabrao. Za mene su, jer radim u srednjoj školi teme spolnosti, seksualnosti i predbračnog života izvrsne teme za razgovor. Zapravo, u službi vjeroučiteljeva poslanja i rada u školi važno je i ovo područje njegova života. Stvar je, zapravo, što gotovo nitko s mladima o tome iskreno ne razgovara, pa kad o tome mi vjeroučitelji pripovijedamo u školi, i kad ja izno- 
sim svoja stajališta o tome, to je ujedno i crkveni stav. Vidi se da te mlade ljude zapravo zanima nešto drugo, nešto više, to kako je Bog divno zamislio nas ljude i koliko je teško u tome ostati postojan. Naime, Crkva savjetuje predbračnu čistoću, nas dvoje smo po Bibliji jedan čovjek, ta druga polovica za mene je uvijek izazov, i tu ne želim nikoga kriviti, ali moram priznati da sam imao sreću što sam sa svojom suprugom živio tu predbračnu čistoću. Jasno mi je da nema idealne situacije. Možda je netko od vjeroučitelja živio drugačije, ali je uvidio da to ipak nije u redu i pokajao se. Ja sam išao ovom prvom linijom, jer sam nekako tako i odgojen u svojoj obitelji, i sve to skupa me je na neki način štitilo. Današnji mentalitet je drugačiji, u brak se stupa što kasnije, pa se to hodanje oduži i na nekoliko godina, a dobro znam da nije jednostavno živjeti baš tu predbračnu čistoću. Istina, teško je, ali je moguće, jer smo mi u tim kriznim situacijama zajedno smislili i molili jednu molitvu pri svakom susretu. Danas s radošću i osmjehom na licima sjećamo tog vremena zajedničkog moljenja (tu se je nasmijao). Bog nam kroz predbračnu čistoću definitivno savjetuje nešto dobro za nas same, samo mi toga nismo do kraja svjesni. Kad s mladima pričam o tome, onda svakako govorim iz iskustva o svim tim pogodnostima i važnosti procesa upoznavanja. Pritom im naglašavam da se ne može nikada upoznati drugu osobu dokraja, da ne znam koliko dugo hodaš s njom, ta niti sam za sebe ne mogu reći da se u potpunosti poznajem. Stoga taj proces upoznavanja pruža mogućnost da se ne ostane zaokupljen samo jednom dimenzijom čovjekova bića, tj. onim tjelesnim. U tome je problem, što današnji mladi zapravo nisu ni svjesni da se upravo vežu samo na taj dio, stoga je dobro da oni čuju da je to moguće, a ne da im se ide na bilo koji način prijetiti. Za njih to puno znači ako sam ja kao vjeroučitelj to mogao i prošao, znači mogu i oni. Bogu hvala, ništa nije slučajno, baš sam došao do tih predavanja i knjige o Teologiji tijela66 kao potvrde svega što nosim u sebi, i kad vidiš da se netko malo stručnije time pozabavio, onda mi to dođe kao dodatno ohrabrenje da sam na dobrom putu i da je to sve skupa jako čudesno" (M. G, 31, 7). ${ }^{67}$

Unatoč svim poteškoćama koje prate življenje sakramenta braka, intervjuirani vjeroučitelji smatraju da je sklapanje crkvenog braka za njih jako bitno iz razloga što drugima predstavljaju vidljivi znak i odraz vjere i duhovnosti da se može živjeti u Crkvi i biti sakra-

66 Ivan Pavao II., Muško i žensko stvori ih - Teologija tijela. Kateheze o ljudskoj ljubavi. Cjelovita teologija tijela. Svezak I i II., Verbum, Split 2012.

67 Kata s. Amabilis Jurić, Duhounost vjeroučitelja vjernika laika u suvremenim hrvatskim crkveno-društvenim uvjetima, Intervju br. 27. 
mentalno vezan, jer za društvo u kojem žive i cjelokupno ozračje ta stvarnost sve više prestaje biti vrednota za koju se isplati založiti čitav život. ${ }^{68}$

\section{UMJESTO ZAKLJUČKA}

Teološka promišljanja o sakramentima pomirenja, euharistije i ženidbe, na koja smo se u najkraćim crtama osvrnuli u ovome radu, po samoj naravi stvari nisu iznijela na vidjelo neku posebnu novost koju već otprije nismo znali, a ta je da sakramenti koje je Isus Krist ustanovio i predao svojoj Crkvi nastoje vjeroučitelja vjernika laika, kao i vjerničku zajednicu primarno voditi u susret Bogu iz kojega proizlazi susret/odnos prema čovjeku, odnosno vjeroučeniku. Svako teološko i pastoralno promišljanje, propitkivanje, osluškivanje i produbljivanje otajstava kršćanske vjere trebalo bi, prema I. Karliću, voditi vjernika, još više vjeroučitelja vjernika laika, prema teološko-pastoralnoj praksi življenja sakramenata kako na osoban način, tako i u zajednici vjernika. Nedvojbeno je da je taj imperativ danas još zahtjevniji, jer se Crkva nalazi pred „vanjskim” izazovima koji bi se mogli svesti na pitanje kako suvremenom čovjeku, koji živi u svijetu snažnog individualizma i „diktature relativizma” na nov način posredovati svete sakramente te kako ga nadahnuti na konkretno življenje u svakodnevnom kršćanskom životu? ${ }^{69}$

Iz navedenih iskaza vjeroučitelja/ica, koji rade u osnovnim i srednjim školama i djeluju u župnim zajednicama, dobivenih iz sociološkog kvalitativnog istraživanja, prepoznajemo odgovore na postavljeno pitanje. Ono što primarno plijeni pozornost, jest činjenica da su vjeroučitelji/ice razumjeli i teorijski usvojili kršćanski nauk o sakramentima, no daleko im se čini važnijim iz konkretnog svjedočkog sakramentalnog života prenositi proživljeno iskustvo na svoje vjeroučenike. Ili, slikovito rečeno, nakon što su sami pili s izvora sakramentalne duhovnosti, mogu to blago ponuditi i svojim vjeroučenicima, u osnovnim i srednjim školama.

68 Da je tomu tako, svjedoče i drugi vjeroučitelji obuhvaćeni kvalitativnim istraživanjem, koji ovdje, zbog prostorne ograničenosti, nisu navedeni. O poteškoćama s kojima se susreću, načinima kako ih rješavaju te konkretnim načinima života sakramenta braka kao i predbračnog života vidi više u: Kata s. Amabilis Jurić, Duhounost vjeroučitelja laika u Hrvatskoj, 293-305.

69 Usp. Ivan Karlić, Sveti sakramenti. Susret s Isusom Kristom u sakramentima Crkve, 291-292. 


\section{RELIGIOUS TEACHERS ON SOME SOURCES OF SACRAMENTAL SPIRITUALITY}

\section{Summary}

It follows from the Catechism of the Catholic Church and the theological literature that the sacraments are the 'focal point' of God's action in the Church and the realization of her saving mission evident in the life and work of the modern religious teacher. The first part of the scientific paper presents the official teaching of the Church and the theological reflections of relevant authors on the sacraments, especially reconciliation, Eucharist and marriage, to which religious teachers paid most attention in qualitative research. Their interpretation relies on some strong points of contemporary Christian sacramentology, which is the subject of the second part of the scientific discourse, which puts at the center of reflection concrete notions and manifestations of the sacramental spirituality obtained by qualitative research, the method of semi-structured or in-depth interview. The interviewed religious teachers confirm the importance of theoretical reflections on the sacraments; however, they still give priority to the concrete witnessing of the adopted contents and transmission to the religious students.

Keywords: sacraments, sacrament of reconciliation, sacrament of the Eucharist, sacrament of marriage, qualitative research, indepth interview. 